\title{
RISK ASSESSMENT OF LOGISTIC ACTIVITIES IN FOREIGN ECONOMIC ACTIVITY AS A COMPONENT OF EFFICIENT MANAGEMENT BY A PHARMACEUTICAL COMPANY
}

\author{
N. Zaharko, R. Sahaidak-Nikitiuk, N. Demchenko
}

Мета. Метою дослідження є розробка методики оцінювання рівня ризику логістичної складової зовнішньоекономічної діяльності (ЗЕД) фармацевтичного підприємства (ФП).

Матеріали та методи. У дослідженні застосовувалися методи узагальнення, аналізу та синтезу, контент-аналізу. Для визначення ризиків логістики в ЗЕД фармацевтичних підприємств застосовувався метод експертного опитування. В опитуванні брали участь провідні фахівці відділів ФП, функиіональні обов 'язки яких пов'язані зі здійсненням ЗЕД. Загальна кількість експертів складає 50 осіб. $100 \%$ респондентів мають вищу освіту, за стажем роботи вони поділяються таким чином: 0-10 років - 11 \%, 11-20 років - $27 \%$, 21-25 років - $53 \%$, понад 25 років - $8 \%$. За гендерною ознакою в опитуванні приймали участь 83 \% жінок і $17 \%$ чоловіків. Висновки експертів є обтрунтованими.

Результати. Визначено, щзо під ризиком логістичної діяльності в сфері ЗЕД фармачевтичного підприємства доцільно розуміти імовірність настання подій в сфері ЗЕД підприємства стосовно управління всіма видами потоків при проходженні ними через кордони краӥни, щзо призводить до певних наслідків у просторі та часі, а саме втрати підприємством частини доходу, іноземних партнерів, затримки виконання обов'язків перед іншими партнерами в наслідок несвоєчасної поставки активних фармацевтичних інгредієнтів (АФІ), итрафів, неустойок тощя. Доведено, щзо до складу ризиків логістичної діяльності в сфері ЗЕД за ознакою виду належать такі підвиди: ризик партнерства, інформаційний, транспортний, інноваційний, організачійний, закупівель імпортних АФІ, основних $i$ допоміжних матеріалів, реалізації (експорту) готових ЛЗ, складування та ризик утраченого зиску.

Висновки. Проведене дослідження дозволило дійти висновку, щуо на ефективність функиіонування ФП впливають і ризики логістичної діяльності в сфері ЗЕД

Ключові слова: фармачевтичне підприємство, ризик, логістична діяльність, управління, оцінювання, лікарські засоби

Copyright @ 2019, N. Zaharko, R. Sahaidak-Nikitiuk, N. Demchenko.

This is an open access article under the CC BY license (http://creativecommons.org/licenses/by/4.0).

\section{Introduction}

In a highly competitive environment with domestic manufacturers of medicines (drugs), as well as importers of similar products, pharmaceutical companies ( $\mathrm{PhCo}$ ) should take into account the specific features and conditions of management in the management of their activities. One of the areas of activity of the $\mathrm{PhCo}$, which allows him to receive significant profits and increase his competitiveness, is foreign economic activity (FEA). In accordance with the Law of Ukraine "On Foreign Economic Activity" No. 959-XII of 16.04.1991 [1], it is appropriate to understand the activities of domestic and foreign economic entities based on the relationship between them, both on the territory of Ukraine, as and beyond.

Any economic activity of the enterprise, especially foreign economic activity, is associated with the emergence of a number of risks that negatively affect the results of its functioning.

2. Formulation of the problem in a general way, the relevance of the theme and its connection with important scientific and practical issues

The issue of the development of foreign economic activity (FEA) of the enterprise and the peculiarities of its strategic planning are highlighted in $[2,3]$; problems of enterprise risk management $[4,5]$; the issue of foreign trade of pharmaceutical enterprises [6, 7]; problems of risk management of the $\mathrm{PhCo}[8,9]$, logistics [10, 11] and logistics risks $[12,13]$. Some questions of risk classification are given in [14].

3. Analysis of recent studies and publications in which a solution of the problem and which draws on the author

However, the research is devoted to risk management in the activities of enterprises, not taking into account the specifics of logistics in the field of foreign economic relations of the pharmaceutical company.

4. Allocation of unsolved parts of the general problem, which is dedicated to the article

The aim of the research is to develop methods of risk assessment FEA of the logistics component of the pharmaceutical company.

\section{Materials and methods}

The study used methods of synthesis, analysis and synthesis, content analysis. To determine the risks of logistics in the foreign trade of pharmaceutical companies, an expert survey method was used.The survey was attended by leading specialists of pharmaceutical companies, whose functional responsibilities are related to the implementation of foreign economic activity. The total 
number of experts was 50 people. $100 \%$ of respondents have a higher education, they are divided into the work experience: $0-10$ years $-11 \%, 11-20$ years $-27 \%, 21-$ 25 years $-53 \%$, over 25 years $-8 \%$. In gender terms in the survey attended $83 \%$ of women and $17 \%$ men. Experts' conclusions are reasonable (determination coefficient -0.824 , which exceeds the threshold value; Pearson's criterion also exceeds the tabular value, taking into account the number of degrees of freedom).

\section{Results and discussion}

Based on the conducted research and content analysis $[15,16]$ it was determined that under the risk of logistics activities of the industrial pharmaceutical enterprise in the field of FEA it is appropriate to understand the probability of occurrence of events concerning the management of all types of flows when they pass through the borders of the country, which leads to certain consequences in space and time (loss of the company part of income, foreign partners, delayed fulfillment of obligations to other partners in the untimely delivery of active pharmaceutical ingredients (API), fines, penalties, etc.).

The variety of sources of risk of logistics in the field of FEA [17] and the peculiarities of the pharmaceutical sector [18], the products produced by $\mathrm{PhCo}$ and its social orientation, the high requirements set forth in the appropriate pharmaceutical practices of GxP in all areas of activity, from the development stage medicines and ending with the utilization of the generated pharmaceutical waste and cause a large number of risks associated with the implementation of logistics activities in the field of foreign economic relations that will require study, analysis, evaluation and management to minimize them and, consequently, improve the enterprise as a whole.

It is advisable to assess the risks of the logistic component of the FEA of the pharmaceutical company on the basis of qualitative analysis, which is conditioned by the possibility of its conduct in any time period and ease of use. Its main objective is to identify all possible risks, identify the factors affecting them and the types of uncertainty and conflicts that cause them, as well as risk areas.

Based on the questionnaire of leading experts, it is determined that the risks of logistics in the field of FEA on the basis of the type that is most important for the effective implementation of FEA, include the following subspecies: partnership risk $\left(\mathrm{x}_{1}\right)$, informational $\left(\mathrm{x}_{2}\right)$, transport $\left(\mathrm{x}_{3}\right)$, innovative $\left(\mathrm{x}_{4}\right)$, organizational $\left(\mathrm{x}_{5}\right)$, purchases of imported API, main and auxiliary materials $\left(\mathrm{x}_{6}\right)$, sale (export) of finished medical supplies $\left(\mathrm{x}_{7}\right)$, warehousing $\left(\mathrm{x}_{8}\right)$ and loss of profit $\left(\mathrm{x}_{9}\right)$. Histogram distribution logistics risks in FEA, determined on the basis of a questionnaire, shown in Fig. 1.

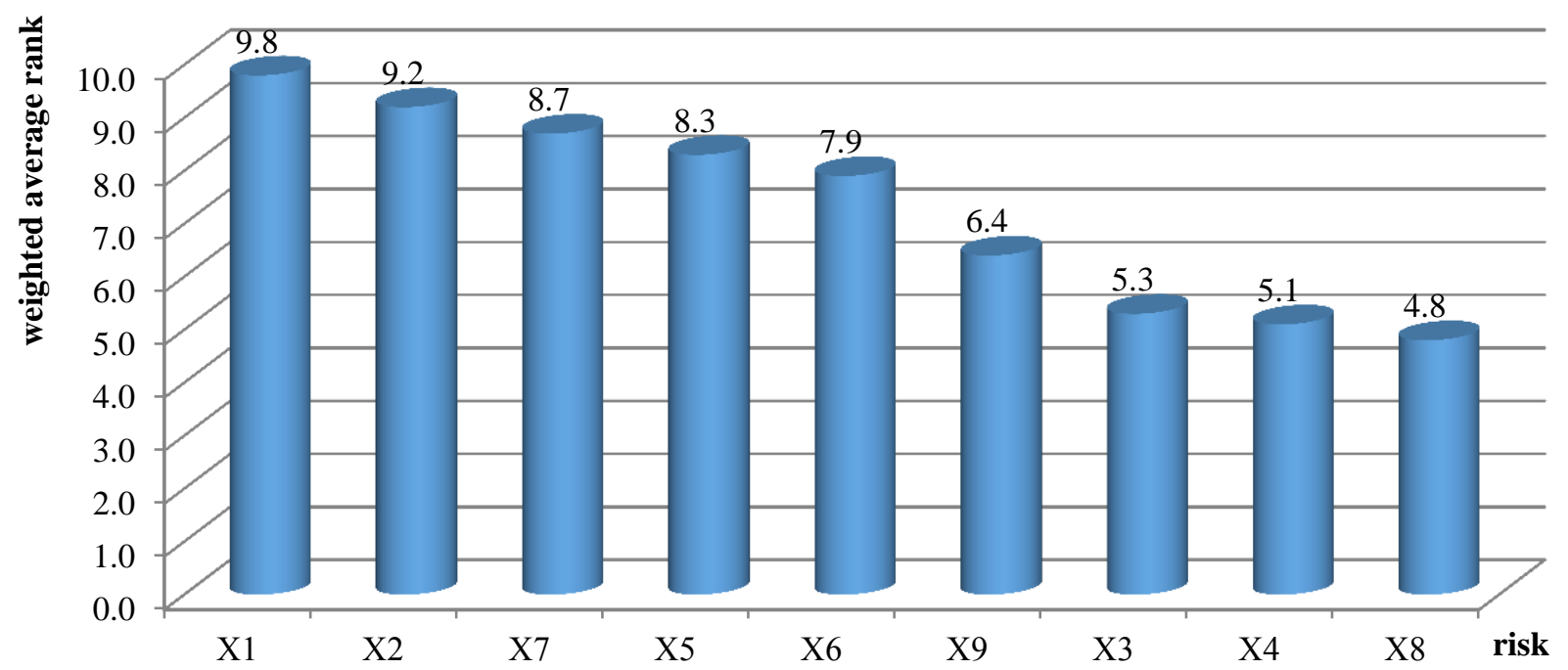

Fig. 1. Histogram of the distribution of types of logistics activities risks in FEA characteristic for pharmaceutical enterprises

Each of the types of listed risks of logistics has certain components. The partnership risks include risks: partner's unreliability $\left(\mathrm{x}_{11}\right)$, mistakes in choosing a partner $\left(\mathrm{x}_{12}\right)$, lack of information about the partner $\left(\mathrm{x}_{13}\right)$, failure to fulfill contractual obligations from the partner $\left(\mathrm{x}_{14}\right)$, termination of relations with partners $\left(\mathrm{x}_{15}\right)$, emergence of conflict situations $\left(\mathrm{x}_{16}\right)$, personal hostility of specialists who represent pharmaceutical enterprises $\left(\mathrm{x}_{17}\right)$, dissolution of established relations with partners $\left(\mathrm{x}_{18}\right)$ (Fig. 2). 


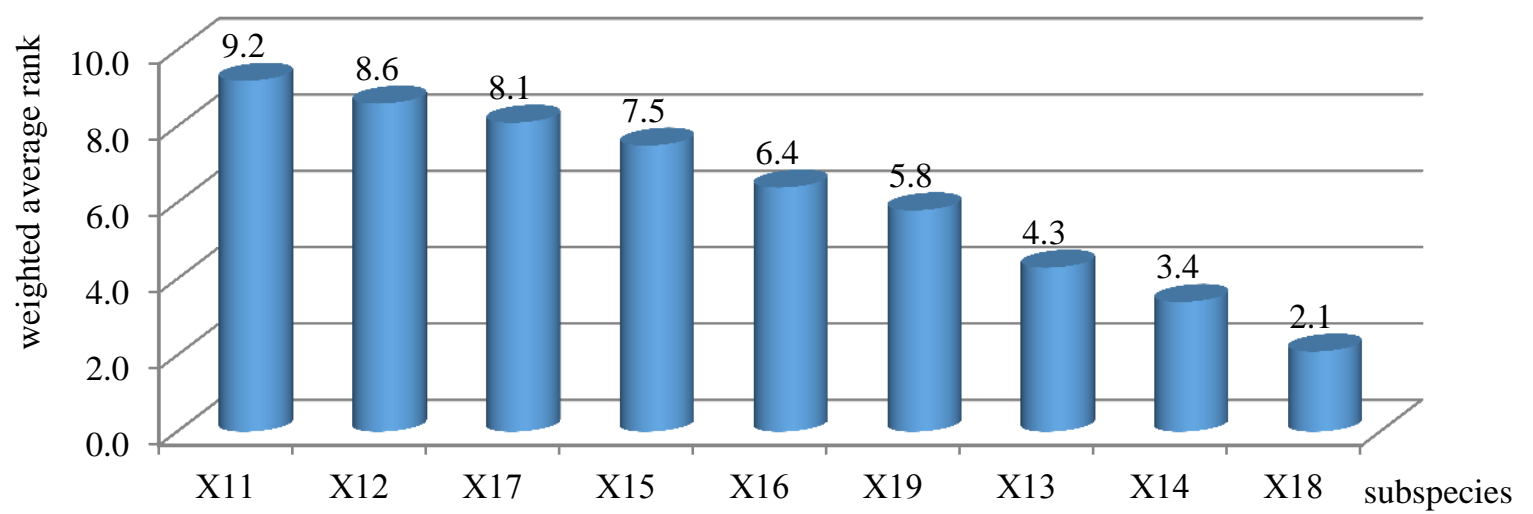

Fig. 2. Distribution risk histogram in the field of FEA, inherent pharmaceutical enterprises

The transport risk in the field of FEA is one of the most significant risks caused by the high requirements for the process of transportation both of finished drugs and API and the need to adhere to highquality drugs aimed at improving human health and should not adversely affect its health.Transport risk arises between $\mathrm{PhCo}$, its partners, the exporters of the API, the main and auxiliary materials, or the $\mathrm{PhCo}$, and the firms that the company exports the finished medicines in the process of transportation and are discovered when the material assets are transferred from one side to the other. This type of risk includes the risks of a vehicle failure $\left(\mathrm{x}_{31}\right)$, its improper choice of vehicle $\left(\mathrm{x}_{32}\right)$, unforeseen delays during the journey $\left(\mathrm{x}_{33}\right)$, mismatch of the vehicle body, proper storage and transportation practicerequirements $\left(\mathrm{x}_{34}\right)$, the driver's loss of documents $\left(x_{35}\right)$, the discrepancy of the vehicle with the requirements of the country in which it travels $\left(\mathrm{x}_{36}\right)$, the discrepancy of the vehicle with the volume of procurement $\left(\mathrm{x}_{37}\right)$, low qualification of drivers of vehicles $\left(\mathrm{x}_{38}\right)$, unreasonable route selection $\left(\mathrm{x}_{39}\right)$, failure of GPS-navigators $\left(\mathrm{x}_{310}\right)$ (Fig. 3).

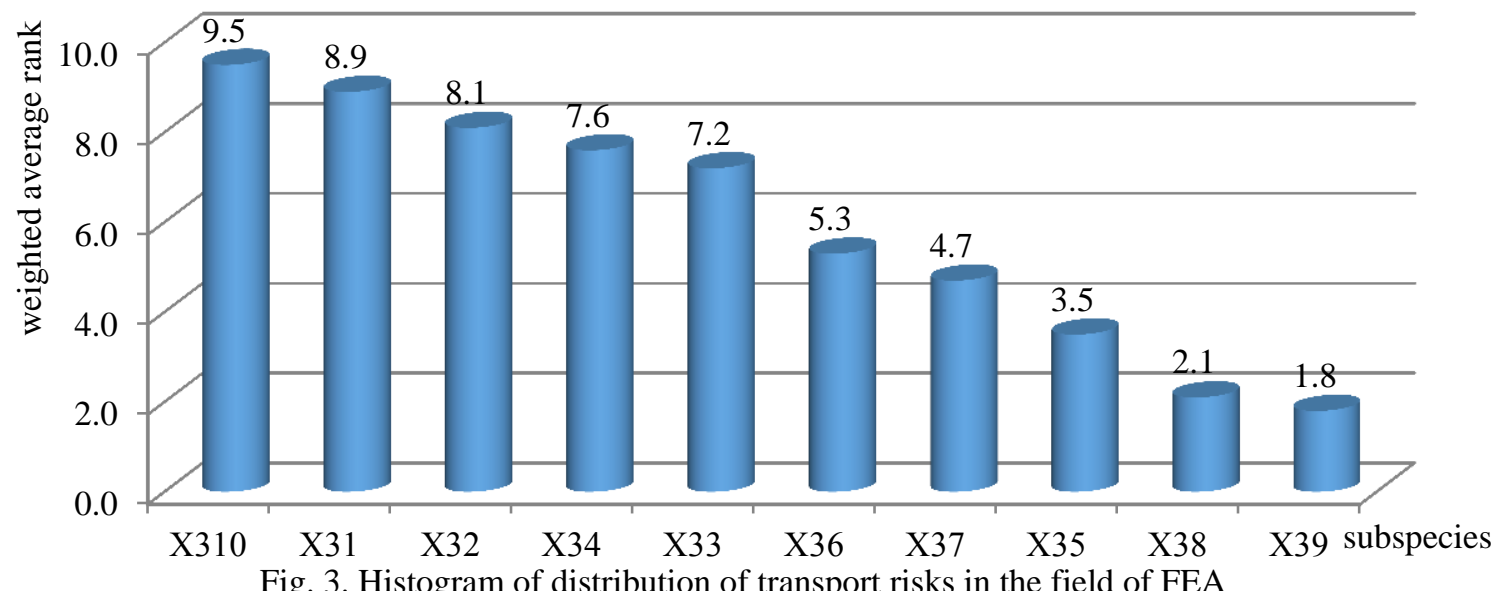

Based on the research conducted, it was determined that the risk of purchasing should be considered as the risks arising from the purchase of $\mathrm{APhI}$, the main and auxiliary materials to the importer, namely: the risk of error in the volumes of purchased API, main and auxiliary materials $\left(\mathrm{x}_{61}\right)$, assortment $\left(\mathrm{x}_{62}\right)$ the time of purchase $\left(\mathrm{x}_{63}\right)$, the purchase of inappropriate quality $\left(\mathrm{x}_{64}\right)$, lack of necessary API $\left(\mathrm{x}_{65}\right)$ and necessary volumes $\left(\mathrm{x}_{66}\right)$ from the supplier; change of volumes of suppliers of API $\left(\mathrm{x}_{67}\right)$; changes of the supplier of assortment $\left(\mathrm{x}_{68}\right)$; absence of registration API $\left(\mathrm{x}_{69}\right)$, supply changes with delivery time $\left(\mathrm{x}_{610}\right)$, supply disruption $\left(\mathrm{x}_{611}\right)$, violation of terms $\left(\mathrm{x}_{612}\right)$ and completeness $\left(\mathrm{x}_{613}\right)$ (Fig. 4$)$.
The risk of storage in customs warehouses $\left(\mathrm{x}_{8}\right)$ is a risk that arises in case of need for the temporary storage of drugs, API, basic and auxiliary materials, etc. in customs warehouses, namely: the risk of inappropriate storage conditions $\left(\mathrm{x}_{81}\right)$, lack of documentation concerning storage conditions $\left(\mathrm{x}_{82}\right)$, corruption $\left(\mathrm{x}_{83}\right)$ or theft $\left(\mathrm{x}_{84}\right)$ during storage, inappropriate qualification of the personnel of the customs warehouse, which can lead to damage to the goods stored in the warehouse $\left(\mathrm{x}_{85}\right)$. The histogram determined on the basis of the questionnaire is shown in Fig. 5. 


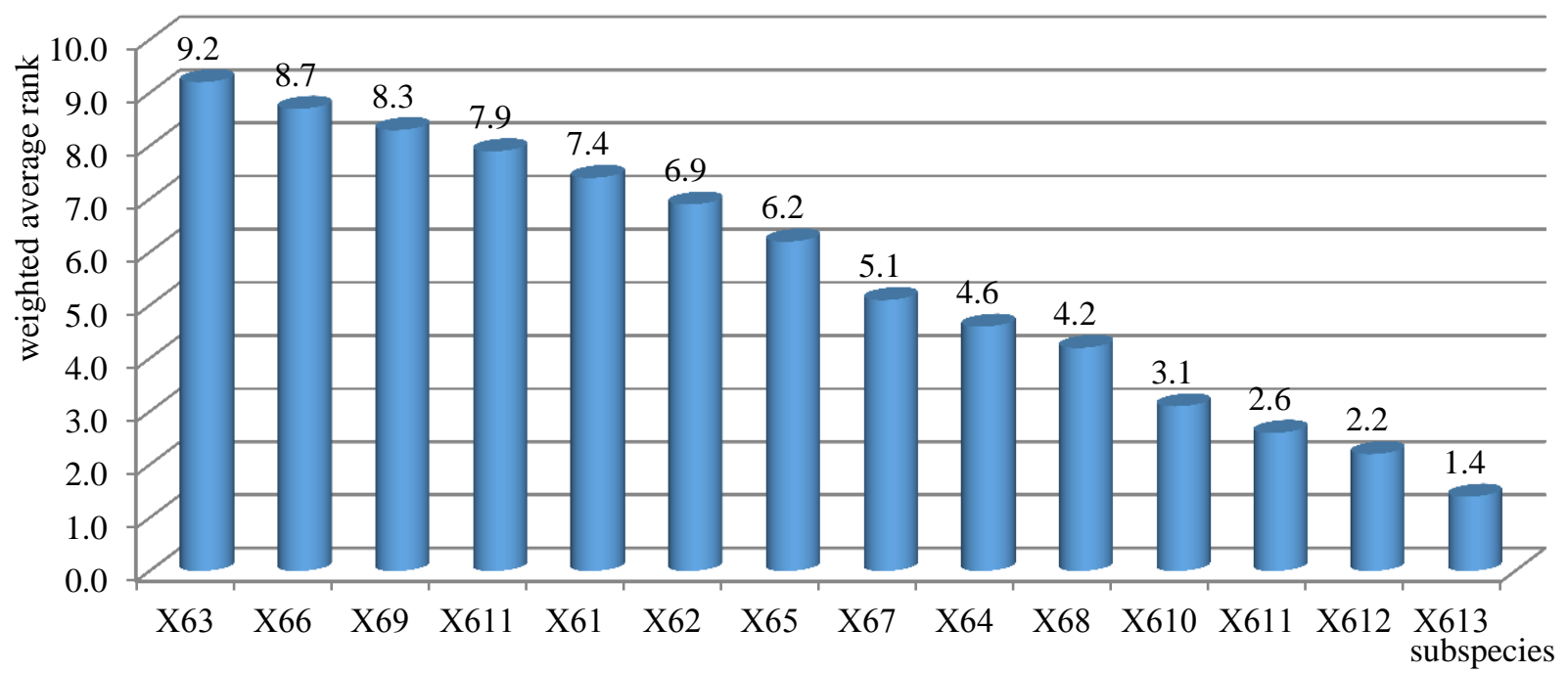

Fig. 4. Histogram risk sharing procurement in the field of FEA

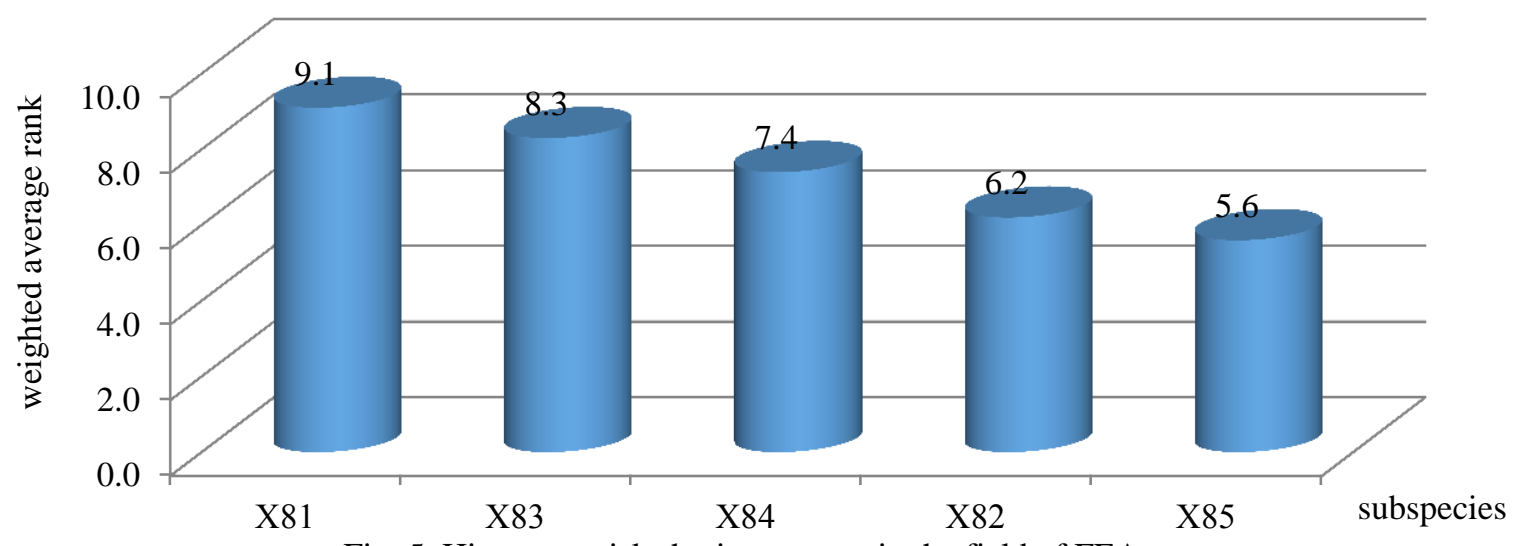

Fig. 5. Histogram risk sharing storage in the field of FEA

Information logistics market in the field of FEA for the conditions of pharmaceutical enterprises - the risk of absence, unreliability and uncertainty of information, which leads to the adoption of groundless decisions, is $5.1 \%$. This leads to the need to attach a certain amount of attention to its components: the risk of unreliability of information, lack of timely information, incomplete information and lack of information at all. The maximum weight falls on the risk of unreliable $(39.1 \%)$ and incomplete $(31.3 \%)$ information.

Organizational risk is a risk due to inaccuracies, mistakes in business, imperfect regulatory and legislative framework, low qualification of logistics personnel, lack of certain standards, etc. The conducted studies allowed us to conclude that the organizational risks of $\mathrm{PhCo}$ in the field of FEA include late timely submission of an application, late timely documentation, errors in the documentation, mistakes in planning the volume of the order, errors in the planning of the range, incomplete documents, inappropriate logistics personnel qualifications, the lack of developed methodological support, the change and imperfection of the regulatory framework for the implementation of foreign economics and logistics activities, lack of documentation, lack of experience of staff, poor planning logistics activities, uncoordinated actions.
Innovative risk of logistics activities in the field of foreign economic activity $\left(\mathrm{x}_{5}\right)$ - the possibility of losses due to shortfall in expected profit from the introduction and use of modern methods, technologies, etc. in logistics to optimize PhCo' logistics activities.

The risk of the implementation of the drug $\left(\mathrm{x}_{7}\right)$ is the risk that occurs in the process of implementation of the finished drugs manufactured by the $\mathrm{PhCo}$, which includes the same components as the risk of API purchasing, due to the similarity of operations.

The next type of risk is the risk of inappropriate logistics service quality $\left(\mathrm{x}_{9}\right)$. Based on the survey, it was determined that the risk of non-delivery of vehicles accounted for $26.15 \%$, the risk of urgent shipment being $13.85 \%$, the risk of improper registration of documents $16.92 \%$, the risk of packaging not in the packaging required by the partner, $-24.62 \%$, change in the cost of logistics services $-18.46 \%$.

The risk of loss of profit $\left(\mathrm{x}_{10}\right)$ is the smallest part among the investigated risks, i.e. the risk of an indirect loss or non-observance of the profit of a PhCo as a result of non-implementation of any measure (insurance, hedging, etc.).

The diversity of the risks of logistics in the field of FEA, as well as their great influence on the efficiency and effectiveness of $\mathrm{PhCo}$ ' activities, and determine the 
relevance of further approaches to their management in order to minimize them.

\section{Conclusions}

1. The definition of "risks of logistics activities in the sphere of foreign economic activity of the pharmaceutical enterprise" is formulated.
2. The types of risks of logistic activity in the field of foreign economic activity of the pharmaceutical enterprise are investigated.

3. The components for each type of risks of logistics activities in the field of foreign trade activity of the pharmaceutical enterprise are determined.

\section{References}

1. Pro zovnishnoekonomichnu diialnist: Zakon Ukrainy No. 959-XII. 16.04.1991. URL: https://zakon.rada.gov.ua/laws/show/ 959-12?find $=1 \&$ text=\%F0 \%E8 \%E7 \%E8 \%EA

2. Orlik I. O. Problems and priorities of development of foreign economic activity of enterprises of trade of Ukraine // Scientific announcer NLTU Ukraine. 2012. Issue 22.2. P. 216-221.

3. Panna A. O. A Role of foreign economic activity is in the increase of competitiveness of agrarian enterprises: proceeding // Advanced technologies of science and education. 2018. URL: http://intkonf.org/panna-ao-rol-zovnishnoekonomichnoyi-diyalnosti-vpidvischenni-konkurentospromozhnosti-agrarnih-pidpriemstv/

4. Istoriia ekonomicheskikh uchenii (sovremennii etap): textbook / ed. by Khudokormov A. G. Moscow: INFRA-M, 2007. $733 \mathrm{p}$.

5. Vitlinskyy V. V., Skitsko V. I. Conceptual grounds of modelling and managing logistics risk of an enterprise // Problemy ekonomiky. 2013. Issue 4. P. 246-253.

6. Zarichkova M. V., Tolochko V. M. Optymizatsiia zovnishnotorhovelnoi diialnosti vitchyznianykh farmatsevtychnykh optovykh ta optovo-rozdribnykh pidpryiemstv (orhanizatsii): handbook. Kharkiv: NFaU, 2008. 28 p.

7. Orhanizatsiia ta ekonomika farmatsii. Part 1. Orhanizatsiia farmatsevtychnoho zabezpechennia naselennia: handbook / ed. by Nemchenko A. S. Kharkiv: NFaU: Zoloti storinky, 2017. 327 p.

8. Lebedinets V. A., Kovalenko S. N. Estimation, analysis and management of quality risks at the pharmaceutical enterprise // Management, Economics and Quality Assurance in Pharmacy. 2011. Issue 6 (20). P. 10-15.

9. Evtushenko H. N., Mnushko Z. N., Nemtsova V. D. A study of risks in the state sector of health protection // Management, Economics and Quality Assurance in Pharmacy. 2010. Issue 4 (12). P. 50-55.

10. Bauersoks D. Dzh., Kloss D. Dzh. Logistiks. Moscow: «OLIMP-BIZNES», 2008. 636 p.

11. Pelenskyy R. A. A specific of logistic is during realization of foreign economic activity by enterprises of Ukraine (FEA) // Naukovyi visnyk LNUVNBT imeni S. Zh. Hzhytskoho. 2012. Vol. 14, Issue 2 (52). Part 4. P. 80-86.

12. Brodetskii G. L. Modelirovanie logisticheskikh sistem. Optimalnye resheniia v usloviiakh riska. Moscow: Vershina, 2006. $376 \mathrm{p}$

13. Krykavskyi Ye. V. Ekonomika lohistychnykh system: monograph / ed. by Krykavskyi Ye. V. Lviv: Vyd-vo Nats. un-tu «Lvivska politekhnika», 2008. 596 p.

14. Pro zabezpechennia masshtabnoi ekspansii eksportu tovariv (robit, posluh) ukrainskoho pokhodzhennia shliakhom strakhuvannia, harantuvannia ta zdeshevlennia kredytuvannia eksportu: Zakon Ukrainy No. 1792-VIII. 20.12.2016. URL: https://zakon.rada.gov.ua/laws/show/1792-19

15. Lohistychnyi menedzhment farmatsevtychnoho pidpryiemstva: monograph / Posylkina O. V., Sahaidak-Nikitiuk R. V., Zahorii H. V., Horbunova O. Yu., Yurchenko A. P. Kharkiv: NFaU, 2011. 772 p.

16. Amitan V. N., Larina R. R., Pliushenko V. L. Lohistyzatsiia protsesiv v orhanizatsiino-ekonomichnykh systemakh: monograph. Donetsk: TOV «Yuho-Vostok, LTD», 2003. 73 p.

17. Sahaidak-Nikitiuk R. V., Posylkina O. V. Metodyka upravlinnia lohistychnymy ryzykamy v umovakh farmatsevtychnoi haluzi // Farmakom. 2009. Issue 3. P. 62-67.

18. The Pharmaceutical Industry in Figures. The European Federation of Pharmaceutical Industries and Associations. URL: https://www.efpia.eu/media/219735/efpia-pharmafigures2017_statisticbroch_v04-final.pdf

Received date 07.05.2019

Accepted date 04.06.2019

Published date 28.06.2019

Natalia Zaharko, Postgraduate Student, Department Processes and Apparatuses of Chemical and Pharmaceutical Industries, National University of Pharmacy,.Pushkinska str., 53, Kharkiv, Ukraine, 61002

E-mail: paft@nuph.edu.ua

Rita Sahaidak-Nikitiuk, Doctor of Pharmacy, Head of Department, Department of Processes and Apparatuses of Chemical and Pharmaceutical Industries, National University of Pharmacy, Pushkinska str., 53, Kharkiv, Ukraine, 61002

E-mail: sagaidak_rita@ukr.net

Natalia Demchenko, PhD, Associate Professor, Department of Management and Administration, National University of Pharmacy, Pushkinska str., 53, Kharkiv, Ukraine, 61002

E-mail: demchenata@ukr.net 